\title{
Prevalence and associated factors of airway hyper- responsiveness in children with recurrent chronic cough
}

\author{
I Gusti Agung Ngurah Sugitha Adnyana, MD; Putu Suwendra, MD; Hendra Santoso, MD
}

\begin{abstract}
Background Airway hyper-responsiveness $(\mathrm{AH})$ is a common characteristic of asthma. Patient who has recurrent chronic cough with $\mathrm{AH}$ is commonly referred as "cough variant asthma". Histamine provocation test should be performed to determine whether a patient has "cough variant asthma" or recurrent viral bronchitis.

Objective To determine $\mathrm{AH}$ prevalence in children with recurrent chronic cough and factors associated with it.

Methods A cross sectional study was conducted on 6-12 year-old children with recurrent chronic cough at the Pediatrics Outpatient Clinic, Sanglah Hospital Denpasar from September 2002 until June 2003

Results Twenty one out of 64 (33\%) subjects suffering from recurrent chronic cough without wheezing had $\mathrm{AH}$. Associated factors significantly associated with $\mathrm{AH}$ were age, allergic rhinitis, paternal and maternal history of atopy, passive smoking, use of mosquito-coil, positive skin prick test, and eosinophilia. Spearman correlation analysis between associated factors and $\mathrm{AH}$ showed that positive skin prick test and passive smoking were moderately correlated with $\mathrm{AH}(\mathrm{r}=0.56, p<0.0001 ; r=0.57, p<0.0001$, respectively), whereas multivariate regression logistic analysis on associated factors found true associated factors, such as positive skin prick test $(p=0.01$; OR=14.82), history of atopy in father $(p=0.02$; $\mathrm{OR}=22.75)$, and passive smoking $(\mathrm{p}=0.03$; $\mathrm{OR}=11.97)$.

Conclusions The prevalence of airway hyper-responsiveness in children with recurrent chronic cough without history of wheezing was $33 \%$. Independent associated factors of $\mathrm{AH}$ in recurrent chronic cough children are positive skin prick test, history of atopy in father, and passive smoking [Paediatr Indones 2004;44:181-187].
\end{abstract}

Keywords: airway hyper-responsiveness, recurrent chronic cough, histamine provocation test, prick test, atopy, passive smoking, cough variant asthma

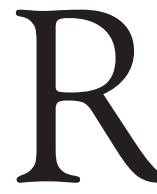

ecurrent chronic cough is defined as the presence of cough lasting for at least 2 weeks and/or cough occurs at least 3 episodes in three consecutive months with or without other respiratory or non-respiratory symptoms (Consensus of KONIKA V 1981, Medan). ${ }^{1}$ Asthma and recurrent viral bronchitis are two common causes of chronic cough in childhood. ${ }^{2}$ History, physical, and supporting examinations are needed to differentiate asthma from recurrent viral bronchitis. ${ }^{3}$ Histamine/ methacholine provocation test is one of the supporting measures to establish airway hyperresponsiveness $(\mathrm{AH})$. Airway hyper-responsiveness itself is a common characteristic of asthma. ${ }^{4,5}$

$\mathrm{AH}$ is the tendency of the airways to constrict more on physical or chemical stimuli. ${ }^{5,6} \mathrm{AH}$ can also be defined as a $20 \%$ fall in $\mathrm{FEV}_{1}$ by a given dose or concentration of a challenging agent. ${ }^{7}$ It is reported that around $40 \%$ of recurrent chronic cough patients have $\mathrm{AH} .{ }^{2}$ Some cross sectional studies on the general population and asthma patients found the association between $\mathrm{AH}$ and some factors such as age, gender, race, positive skin prick test, history of atopy in parents, atopic diseases (asthma, allergic rhinitis, atopic dermatitis, and urticaria), air pollutants (especially cigarette smoke), and eosino-

From the Department of Child Health, Medical School, Udayana University, Sanglah Hospital, Denpasar, Indonesia.

Reprint requests to: IGAN Sugitha Adnyana, MD, Department of Child Health, Medical School, Udayana University, Sanglah Hospital, Denpasar, Indonesia. Tel 62-361-27911, Fax 62-361-224206. 
philia. ${ }^{8-10}$ So far, there has been no study about AH prevalence and its associated factors, such as age, gender, race, positive skin prick test, history of atopy in parents, atopic diseases, air pollutant, and eosinophilia, on recurrent chronic cough patients. The aim of this study was to determine $\mathrm{AH}$ prevalence in children with recurrent chronic cough and its associated factors.

\section{Methods}

This cross sectional study was conducted at the Pediatric Outpatient Clinic, Sanglah Hospital, Denpasar in September 2002 until June 2003. Subjects were selected by consecutive sampling until the minimal sample size required was met (64 subjects). Children aged 6-12 years old suffering from recurrent chronic cough without wheezing were included. Children were excluded if they had pneumonia, lung tuberculosis, asthma, pertussis, cystic fibrosis, heart diseases, neurological diseases, or congenital disorders, or if they did not agree to participate or were not cooperative. This study was approved by the Ethics Committee of Medical School, Udayana University/Sanglah Hospital, Denpasar.

Recurrent chronic cough children who met the inclusion criteria were requested to fill in a questionnaire. Physical and supporting examinations (complete blood count, chest x-ray, Mantoux test) were performed to complete the data. Information about this study was explained to the parents of each subject and an informed consent was signed if they had agreed to participate in this study. Skin prick test and histamine provocation test were performed if the subjects fulfilled the eligibility criteria.

History of atopy in one or both parents was considered present if they had at least one atopic disease such as asthma, allergic rhinitis, atopic dermatitis, or urticaria. ${ }^{10}$ Passive smoking was involuntary inhalation of smoke produced by one or more family members in the house consuming at least six cigarettes a day. ${ }^{11}$ Use of mosquito-coil was defined as usage of mosquito-coil at night for at least 8 hours a day. Eosinophilia was defined as the number of serum eosinophils of $>275 / \mathrm{ml}^{8}$ (Cell-dyn spectrophotometer).
Skin prick test was performed using some common allergen extracts (Extract Allergen Division, Sutomo Hospital, Surabaya), such as environmental allergen (mite, house dust mite), food allergen (peanut, chocolate, tongkol fish, shrimp, apple, soy, wheat), yeast allergen, and animal allergen (featherduster, cat hair, dog hair), with normal saline solution as negative control and histamine $5 \%$ as positive control. Histamine and steroid were withheld for 3 days and 24 hours before the test day, respectively. Skin prick test was performed on the volar surface of the forearm. The skin of the volar surface of the forearms was cleaned with an alcohol and allowed to dry. A grid pattern for putting the allergen was then drawn on the forearm with a ballpoint pen. At each site, a drop of allergen extract solution was placed on the skin, and the skin was gently pricked by placing a $26 \mathrm{G}$ needle at an angle of $45^{\circ}$ to the skin and lifting it so that a small amount of epidermis was abraded. After 15 minutes, an indurations of $>2 \mathrm{~mm}$ was considered positive and subjects with positive test results to at least one extract allergen were considered atopy. ${ }^{12,13}$

$\mathrm{AH}$ with inhaled histamine was measured by a method described by Cockcroft et al. ${ }^{12-14}$ Histamine, steroid, and aminophylline were withheld for 24 hours before the test day, and $b_{2}$-agonist was withheld for 18 hours before the test day. Aerosols of the test solution were generated by a nebulizer (De Vilbiss PulmoAide, Chicago) operated to provide an output of 0.13-0.15 ml/min. Each aerosol was inhaled through the mouth (face mask) by tidal breathing for 2 minutes. The first aerosol was saline solution $(0.9 \%)$, followed in 4-minute intervals by increased concentration of histamine $(0.01 ; 0.1 ; 1 ; 2 ; 4 ; 8 \mathrm{mg} / \mathrm{ml})$. The response was measured by $\mathrm{FEV}_{1}$ (Vitalograph Spirometer, Inc., London, UK), before starting the procedure and 1 minute after each inhalation. Positive histamine provocation test was defined as a decline of $20 \%$ or more in $\mathrm{FEV}_{1}$ from the post saline value after histamine provocation. Negative histamine provocation test was defined as no decline of $20 \%$ or more in $\mathrm{FEV}_{1}$ until concentration of histamine provocation reached $8 \mathrm{mg} / \mathrm{dl}$. The test was terminated when subjects showed a positive result. It was also terminated at the end of the dose when subjects showed no positive result. Salbutamol nebulization was given to subjects with positive test. 
Data were tabulated and analyzed using SPSS ver. 10.0 for Windows program. Associations between dependent variable $(\mathrm{AH})$ and independent variables were tested by chi-square test. Spearman correlation analysis was used to evaluate degree of correlation between associated factors and $\mathrm{AH}$. After univariate analysis was done, multivariate logistic regression analysis was used to find independent associated factors. The level of significance was $\mathrm{p}<0.05$ with $95 \%$ confidence interval.

\section{Results}

\section{Subjects' characteristics}

There were 71 children aged 6-12 years who had recurrent chronic cough without wheezing. From these children, 64 were included in this study and 7 were excluded ( 1 did not agree to participate, 3 had lung tuberculosis, 1 had pneumonia, 2 were not cooperative). Thirty-four of 64 subjects (53\%) were boys and $30(47 \%)$ were girls. The characteristics of the subjects can be seen in Table 1 .

Table 1. Characteristics of the subjects

\begin{tabular}{lcc}
\hline & Total $(\mathbf{n}=64)$ & Percentage \\
\hline Age, mean (SD), year & $7.80(1.89)$ & \\
Gender, male & 34 & 53 \\
Allergic rhinitis & 9 & 14 \\
Atopic dermatitis & 12 & 19 \\
Urticaria & 19 & 30 \\
History of atopy in father & 18 & 28 \\
History of atopy in mother & 22 & 34 \\
History of atopy in both parents & 6 & 9 \\
Passive smoking & 19 & 30 \\
Use of mosquito-coil & 30 & 47 \\
Positive skin prick test & 24 & 38 \\
Eosinophilia & 29 & 53 \\
\hline
\end{tabular}

\section{Prevalence}

$\mathrm{AH}$ prevalence in children with recurrent chronic cough without wheezing was 21 of $64(33 \%)$. AH prevalence in 6-9 year-old subjects was $23 \%$, and in 9-12 year-old was 10/17. Sixteen of 24 subjects with positive skin prick test had $\mathrm{AH}$. AH prevalence in passive smokers was $14 / 19$. Six of 9 subjects with allergic rhinitis had $\mathrm{AH}$, whereas 5 of 6 subjects with history of atopy in both parents had $\mathrm{AH}$. AH prevalence based on various characteristics can be seen in Table 2.
Table 2. Prevalence Ratio of associated factors of aH

\begin{tabular}{|c|c|c|c|c|c|c|}
\hline & $\begin{array}{c}\mathrm{AH} \\
\mathrm{n}=21\end{array}$ & $\begin{array}{c}\text { Non } A H \\
n=43\end{array}$ & PR & $95 \% \mathrm{Cl}$ & & $\begin{array}{c}p \\
\text { value }\end{array}$ \\
\hline \multicolumn{7}{|l|}{ Sex } \\
\hline Male & 12 & 22 & 1.18 & $0.578 ; 2.396$ & & 0.65 \\
\hline Female & 9 & 21 & & & & \\
\hline \multicolumn{7}{|l|}{ Age } \\
\hline $6-9$ years & 11 & 36 & 0.40 & $0.207 ; 0.764$ & & 0.01 \\
\hline$>9-12$ years & 10 & 7 & & & & \\
\hline \multicolumn{7}{|c|}{ Allergic rhinitis } \\
\hline Yes & 6 & 3 & 2.44 & $1.299 ; 4.600$ & & 0.04 \\
\hline No & 15 & 40 & & & & \\
\hline \multicolumn{7}{|c|}{ Atopic dermatitis } \\
\hline Yes & 6 & 6 & 1.73 & $0.853 ; 3.521$ & & 0.15 \\
\hline No & 15 & 37 & & & & \\
\hline \multicolumn{7}{|l|}{ Urticaria } \\
\hline Yes & 9 & 10 & 1.78 & $0.902 ; 3.498$ & & 0.10 \\
\hline No & 12 & 33 & & & & \\
\hline \multicolumn{7}{|c|}{$\begin{array}{l}\text { History of atopy } \\
\text { in father }\end{array}$} \\
\hline Yes & 10 & 8 & 2.32 & $1.200 ; 4.498$ & 1 & 0.01 \\
\hline No & 11 & 35 & & & & \\
\hline \multicolumn{7}{|c|}{$\begin{array}{l}\text { History of atopy } \\
\text { in mother }\end{array}$} \\
\hline Yes & 11 & 11 & 2.10 & $1.060 ; 4.160$ & 1 & 0.03 \\
\hline No & 10 & 32 & & & & \\
\hline \multicolumn{7}{|c|}{$\begin{array}{l}\text { History of atopy } \\
\text { in both parents }\end{array}$} \\
\hline Yes & 5 & 1 & 3.02 & $1.744 ; 5.233$ & & 0.01 \\
\hline No & 16 & 42 & & & & \\
\hline \multicolumn{7}{|c|}{ Passive smoking } \\
\hline Yes & 14 & 5 & 4.74 & $2.278 ; 9.848$ & & 0.00 \\
\hline No & 7 & 38 & & & & \\
\hline \multicolumn{7}{|c|}{$\begin{array}{l}\text { Use of mosquito } \\
\text {-coil }\end{array}$} \\
\hline Yes & 14 & 16 & 2.27 & $1.057 ; 4.861$ & & 0.02 \\
\hline No & 7 & 27 & & & & \\
\hline \multicolumn{7}{|c|}{ Skin prick test } \\
\hline Positive & 16 & 8 & 5.33 & $2.240 ; 12.696$ & & 0.00 \\
\hline Negative & 5 & 35 & & & & \\
\hline \multicolumn{7}{|l|}{ Eosinophilia } \\
\hline Yes & 14 & 15 & 2.41 & $1.126 ; 5.173$ & & 0.01 \\
\hline No & 7 & 28 & & & & \\
\hline
\end{tabular}

$\mathrm{PR}=$ prevalence ratio; $95 \% \mathrm{Cl}=95 \%$ confidence interval

\section{Prevalence ratio of factors associated with AH}

Factors associated with $\mathrm{AH}$ in children with recurrent chronic cough were age, allergic rhinitis, history of atopy in father, mother, and both parents, passive smoking, use of mosquito-coil, positive skin prick test, and eosinophilia. All of these had significant PR; the PR and their 95\% confidence interval are depicted in Table 2. Positive skin prick test had the highest prevalence ratio $(\mathrm{PR}=5.33 ; 95 \% \mathrm{CI} 2.24 ; 12.69)$. In this study, one protective factor was age of 6-9 years. The prevalence ratio of this protective factor was less than 1 i.e., 0.40 with $95 \% \mathrm{CI}$ of $0.21 ; 0.76$. 
Correlation between associated factors and $\mathrm{AH}$

There were significant correlations between some associated factors and AH. Table 3 shows correlation coefficients and $\mathrm{p}$ values of some variables by Spearman correlation test. There was a negative correlation between $\mathrm{AH}$ and age of $6-9$ years $(\mathrm{r}=-0.33)$. The strongest correlation was found between passive smoking and $\mathrm{AH}(\mathrm{r}=0.57)$, followed by that between positive skin prick test and $\mathrm{AH}(\mathrm{r}=0.56)$.

Correlation coefficients of more than 0.5 were found between both passive smoking and positive skin prick test and $\mathrm{AH}$, which meant that these factors were moderately correlated with $\mathrm{AH}$.

\section{Multivariate logistic regression analysis on factors associated with $\mathrm{AH}$}

By multivariate logistic regression analysis on some factors associated with $\mathrm{AH}$, we found only three independent associated factors i.e., positive skin prick test $(\mathrm{OR}=14.82,95 \% \mathrm{CI} 1.96 ; 111.95, \mathrm{p}=0.01)$, history of atopy in father $(\mathrm{OR}=22.75,95 \% \mathrm{CI} 1.76$; 294.68, $\mathrm{p}=0.02)$, and passive smoking $(\mathrm{OR}=11.97$, 95\%CI 1.23;116.46, $\mathrm{p}=0.03$ ) (Table 4).

\section{Discussion}

The prevalence of $\mathrm{AH}$ by histamine provocation test on recurrent chronic cough patients depends on risk factors and conditions at the time the test is performed.
Some risk factors which can influence $\mathrm{AH}$ are atopy status, smoke, and air pollutants. ${ }^{15,16}$

Sovijarvi et al ${ }^{17}$ found that the prevalence of $\mathrm{AH}$ (by a rapid dosimetric method) in chronic cough patients was 20\%, whereas Cockcroft et al ${ }^{18}$ found that the prevalence of $\mathrm{AH}$ in patients with cough without other chest symptom was $47 \%$. In this study, we found that the prevalence of $\mathrm{AH}$ as determined by histamine provocation test in patients with recurrent chronic cough without wheezing was 33\%. This result was higher than that of Sovijarvi's study, possibly due to the difference in provocation test method.

Sparrow et $a l^{19}$ in their study on asthma patients show that nonspecific airway responsiveness will increase along with the increase of age. In our study, AH prevalence in 6-9 year-old group (23\%) was lower than that in $9-12$ year-old group (10/17). This difference was significant statistically, but on multivariate logistic regression analysis if was found that age was not associated with $\mathrm{AH}$. The prevalence of $\mathrm{AH}$ in older children was higher because the increase of age will cause longer child induction by irritant agent (cigarette smoke, mosquito-coil) and allergen, so that inflammation process will be more serious.

Sears et $a^{20}$ reported that male sex was a predicting factor for $\mathrm{AH}$. In our study, we found that $\mathrm{AH}$ prevalence in male subjects was higher than that in female subjects, but this difference was not significant statistically. This result was similar to the study of Peat et al in Australia. ${ }^{9}$

Table 3. Spearman correlation matrix between associated factors and AH

\begin{tabular}{ccccccccccc}
\hline & AH & Age & $\begin{array}{c}\text { Allergic } \\
\text { rhinitis }\end{array}$ & $\begin{array}{c}\text { History } \\
\text { of atopy } \\
\text { in father }\end{array}$ & $\begin{array}{c}\text { History } \\
\text { of atopy } \\
\text { in mother }\end{array}$ & $\begin{array}{c}\text { History } \\
\text { of atopy } \\
\text { in both } \\
\text { parents }\end{array}$ & $\begin{array}{c}\text { Passive } \\
\text { smoking }\end{array}$ & $\begin{array}{c}\text { Use of } \\
\text { mosquito } \\
\text {-coil }\end{array}$ & $\begin{array}{c}\text { Passive } \\
\text { skin prick } \\
\text { test }\end{array}$ & $\begin{array}{c}\text { Eosi } \\
\text { nophilia }\end{array}$ \\
\hline $\mathrm{AH} \quad \mathrm{r}$ & 1.000 & $\mathbf{- 0 . 3 3 3}$ & 0.292 & 0.303 & 0.265 & 0.346 & $\mathbf{0 . 5 6 6}$ & 0.277 & $\mathbf{0 . 5 5 9}$ & 0.300 \\
& $\mathrm{p}$ & 0.007 & 0.019 & 0.015 & 0.034 & 0.005 & 0.000 & 0.027 & 0.000 & 0.016 \\
\hline
\end{tabular}

Table 4. Multivariate logistic regression analysis on associated factors of AH

\begin{tabular}{lcccc}
\hline & B & $\boldsymbol{P}$ value & RO & $\mathbf{9 5 \%} \mathbf{C l}$ \\
\hline Age & -1.54 & 0.14 & 0.21 & $0.027 ; 1.686$ \\
Allergic rhinitis & 0.23 & 0.85 & 1.26 & $0.106 ; 4.950$ \\
History of atopy in father & 3.12 & $\mathbf{0 . 0 2}$ & 22.75 & $1.757 ; 294.683$ \\
History of atopy in mother & 0.51 & 0.68 & 1.66 & $0.143 ; 19.253$ \\
History of atopy in both parents & -2.62 & 0.26 & 0.07 & $0.001 ; 7.055$ \\
Passive smoking & 2.48 & $\mathbf{0 . 0 3}$ & 11.97 & $1.231 ; 116.458$ \\
Use of mosquito-coil & 0.73 & 0.41 & 2.08 & $0.364 ; 11.919$ \\
Positive skin prick test & 2.70 & $\mathbf{0 . 0 1}$ & 14.82 & $1.963 ; 111.947$ \\
Eosinophilia & 0.75 & 0.41 & 2.12 & $0.354 ; 12.705$ \\
\hline
\end{tabular}

$\mathrm{B}=$ logistic regression coefficient; OR = Odds ratio; $95 \% \mathrm{Cl}=95 \%$ confidence interval 
In allergic rhinitis, mucosal mast cells or basophils are induced by allergen, resulting in nasal reactions (early and late types). These reactions will cause itching, mucosal edema, hypersecretion, or mucosal damage that will disturb mucociliary transport. Malfunction of mucociliary transport will raise the probability of sinusitis. Postnasal drip resulting from sinusitis causes inflammation of bronchial mucosa and increases $\mathrm{AH}$.

A study on 27 allergic rhinitis patients found that 15 patients had $\mathrm{AH} .{ }^{21}$ Backer et al $^{10}$ found that atopic diseases such as asthma, allergic rhinitis, and atopic dermatitis in children are significantly associated with $\mathrm{AH}(\mathrm{p}=0.001)$. However, they did not find $\mathrm{AH}$ in children with urticaria. In our study we found that 6 of 9 recurrent chronic cough patients who had allergic rhinitis had $\mathrm{AH}$; whereas $\mathrm{AH}$ prevalence in recurrent chronic cough patients who had atopic dermatitis and in those with urticaria was $6 / 12$ and 9/19 respectively. Statistically, atopic dermatitis and urticaria were not associated with AH. Multivariate logistic regression analysis showed that there was no association between allergic rhinitis and $\mathrm{AH}$.

Cigarette smoke is the main air pollutant. According to Miltzer, cigarette smoke contains chemicals such as nicotine, tar, and carbon monoxide which can be hazardous to the respiratory epithelium. ${ }^{22}$ The damage to respiratory epithelium causes epithelial cell unable to prevent inhalant allergen penetration to go further into the airway mucosa and react with target cells. Unimpaired epithelial cells produce neural endopeptidase (which is able to neutralize P substance) and epithelial derived relaxing factor (EpDRF). Both prevent bronchoconstriction, edema, and inflammation of the airways. The damage to mucosal epithelial cells was increased by inflammatory mediators. ${ }^{15,16,23}$ Constant contact with cigarette smoke affects $\mathrm{FEV}_{1}$. The effect of cigarette smoke occurs not only in active smokers, but also in children of smoking parents (passive smokers). ${ }^{22}$

Martinez et $a l^{24}$ stated that the prevalence of $\mathrm{AH}$ in male children of smoking parents was significantly higher compared to that in those of non-smoking parents $(\mathrm{OR}=4.3, \mathrm{p}=0.009)$. Frischer et $a^{25}$ showed that $\mathrm{AH}$ occurs more often in children exposed to maternal smoking in their first year of life $(\mathrm{OR}=2.82$; 95\%CI 1.25;6.34; $\mathrm{p}<0.01$ ) and Forastiere et $a^{26}$ reported that maternal and paternal smoking are strong predictors of $\mathrm{AH}$.
In our study, $\mathrm{AH}$ prevalence in recurrent chronic cough patients with passive smoking was $14 / 19$. In univariate analysis, AH was significantly associated with passive smoking and use of mosquitocoil, whereas in multivariate logistic regression analysis, we found only passive smoking as an independent associated factor of $\mathrm{AH}(\mathrm{OR}=11.97 ; 95 \% \mathrm{CI}$ $1.231 ; 116.458 ; \mathrm{p}=0.03)$.

Backer et $a^{27}$ found that the degree of $\mathrm{AH}$ by inhaled histamine is significantly related to history of asthma in the two first-degree relatives $(\mathrm{p}<0.001)$. Caultas and Slamet showed that the prevalence of asthma in children whose parents both had atopy was higher than those with atopy in only one parent. ${ }^{22}$ In our study, AH prevalence in recurrent chronic cough children with history of atopy in father, mother, and both parents was 10/18, 11/22, and $5 / 6$, respectively. In univariate analysis, it was found that $\mathrm{AH}$ was significantly associated with history of atopy in father, mother, and both parents, while in multivariate logistic regression analysis, history of atopy in father was the only independent associated factor of $\mathrm{AH}(\mathrm{OR}=22.75$; 95\%CI 1.757;294.683; $\mathrm{p}=0.02$ ). These results may be due to the small number of subjects with history of atopy in both parents in our study.

Postma et al ${ }^{28}$ concluded that a trait for an elevated level of serum total $\mathrm{IgE}$ is coinherited with a trait for $\mathrm{AH}$ and that the gene governing $\mathrm{AH}$ is located near a major locus that regulates serum IgE levels on chromosome $5 \mathrm{q} 31-\mathrm{q} 33$. This data provides strong evidence of one or more susceptibility loci on chromosome $5 \mathrm{q} 31-\mathrm{q} 33$ that contribute to $\mathrm{AH}$ and atopy.

In our study, $\mathrm{AH}$ prevalence in recurrent chronic cough children with positive skin prick test was $16 / 24$. In univariate analysis, it was found that positive skin prick test was significantly associated with $\mathrm{AH}$ and in multivariate logistic regression analysis we found positive skin prick test as an independent associated factor of $\mathrm{AH}(\mathrm{OR}=14.82$; 95\%CI $1.963 ; 111.947 ; \mathrm{p}=0.01$ ).

Martinez et al ${ }^{24}$ reported that $\mathrm{AH}$ is significantly associated with atopy (positive skin prick test) $(\mathrm{p}=0.001)$. Peat et $a l^{9}$ concluded that atopy (positive skin prick test) is the most important risk factor for $\mathrm{AH}$ in all ages.

In asthma, the number of eosinophils increases in the bronchial submucosa. Thus, the degree of $\mathrm{AH}$ 
is associated with the number of eosinophils in the wall of airways. Eosinophilia indirectly induces $\mathrm{AH}$. The presence of both eosinophilia and $\mathrm{AH}$ indicates a more activated immunologic process in the airways. Eosinophilia may reflect a higher number of eosinophils in the airway mucosa. ${ }^{8}$ The association between higher peripheral blood eosinophil counts and $\mathrm{AH}$ was found in some studies. ${ }^{29-31}$ In our study, AH prevalence in recurrent chronic cough children with eosinophilia was 14/29. In univariate analysis, eosinophilia was significantly associated with $\mathrm{AH}$ in children with recurrent chronic cough, but in logistic regression analysis we found that eosinophilia was not an independent factor of $\mathrm{AH}$. These results are possible because eosinophilia can be caused by helminthic and allergic diseases; ${ }^{32}$ helminthic infection is still prevalent in our area.

In conclusion, $\mathrm{AH}$ prevalence in children with recurrent chronic cough without history of wheezing is $33 \%$. Independent associated factors of $\mathrm{AH}$ in recurrent chronic cough children are positive skin prick test, history of atopy in father, and passive smoking. We advise family members to stop smoking inside the house. More studies with case-control or cohort design should be done to control the confounding variables.

\section{References}

1. Rahajoe N, Supriyatno B, Chatab F. Batuk kronik dan/ atau berulang pada anak: tinjauan khusus pengaruh sinusitis. In: Rahajoe N, Rahajoe NN, Budiman I, editors. Perkembangan dan masalah pulmonologi anak saat ini. Jakarta: FKUI; 1994. p. 129-42.

2. Van Asperen PP. Chronic and recurrent cough in children: an Australian experience. In: Rahajoe N, Rahajoe NN, Budiman I, editors. Perkembangan dan masalah pulmonologi anak saat ini. Jakarta: FKUI; 1994. p. 103-27.

3. Faniran AO, Peat JK, Woolcock AJ. Persistent cough: is it asthma? Arch Dis Child 1998;79:411-4.

4. Neijens HJ. Bronchial hyperreactivity. In: Tjokronegoro A, Cornain S, Widowati R, editors. Allergy and immunology in Asian-Pacific region. Jakarta: Perhimpunan Alergi dan Imunologi Indonesia; 1989. p. 3-4.

5. Cockroft DW, Hargreave FE. Airway hyper-responsiveness: definition, measurement, and clinical relevance.
In: Kaliner MA, Barnes PJ, Persson CGA, editors. Asthma: its pathology and treatment. New York: Marcel Dekker Inc; 1991. p. 51-72.

6. Bratawidjaja K. Hiperreaktivitas saluran napas. Maj Kedokt Indones 1989;39:111-5.

7. Van Asperen PP. Atopy, bronchial hyper-responsiveness and inflammation in childhood asthma. In: Rahajoe N, Rahajoe NN, Budiman I, editors. Perkembangan dan masalah pulmonologi anak saat ini. Jakarta: FKUI; 1994. p. 183-91.

8. Jansen DF, Schouten JP, Vonk JM, Rijcken OB, Timens W, Kraan J, et al. Smoking and airway hyper-responsiveness especially in the presence of blood eosinophilia, increase the risk to develop respiratory symptoms: a 25-year follow-up study in general adult population. Am J Respir Crit Care Med 1999;160:259-64.

9. Peat JK, Salome CM, Woolcock AJ. Factors associated with bronchial hyper-responsiveness in Australian adults and children. Eur Respir J 1992;5:921-9.

10. Backer V, Bach-Mortensen N, Dirksen A. Prevalence and predictors of bronchial hyper-responsiveness in children aged 7-16 years. Allergy 1989;44:214-9.

11. Weitzman M, Gortmaker S, Walker DK, Sobol A. Maternal smoking and childhood asthma. Pediatrics 1990;85:505-11.

12. Ulrik CS. Bronchial responsiveness to inhaled histamine in both adults with intrinsic and extrinsic asthma: the importance of prechallenge forced expiratory volume in 1 second. J Allergy Clin Immunol 1993;91:120-6.

13. Bryant DH, Boscato LM, Mboloi PN, Stuart MC. Allergy to laboratory animals among animal handlers. Med J Aust 1995;163: 415-8.

14. Ulrik CS. Factors associated with increased bronchial responsiveness in adolescents and young adult: The importance of adjustment for prechallange $\mathrm{FEV}_{1}$. J Allergy Clin Immunol 1996;97:761-7.

15. Budiman I. Peranan dan penanggulangan inflamasi sebagai upaya pencegahan dan tatalaksana asma pada anak. In: Rahajoe N, Rahajoe NN, Budiman I, editors. Perkembangan dan masalah pulmonologi anak saat ini. Jakarta: FKUI; 1994. p.193-200.

16. Sheffer AL. Definition and diagnosis of asthma. J Allergy Clin Immunol 1991;88:425-35.

17. Sovijarvi AR, Malmberg LP, Reinikainen K, Rytila P, Poppius $\mathrm{H}$. A rapid dosimetric method with controlled tidal breathing for histamine challenge. Repeatability and distribution of bronchial reactivity in a clinical material. Chest 1993;104:164-70. 
18. Cockcroft DW, Killian DN, Mellon JJA, Hargreave FE. Bronchial reactivity to inhaled histamine: a method and clinical survey. Clin Allergy 1977;7:235-43.

19. Sparrow D, O'Connor GT, Rosner B, Segal MR, Weiss ST. The influence of age and level of pulmonary function on non specific airway responsiveness: the normative aging study. Am Rev Respir Dis 1991;143:978-82.

20. Sears MR, Holdaway MD, Flannery EM, Herbison GP, Silva PA. Parental and neonatal risk factors for atopy, airway hyper-responsiveness, and asthma. Arch Dis Child 1996;75:392-8.

21. Reed CE, Townley RG. Asthma classification and pathogenesis. In: Middleton E, Reed CE, Eclis EF, editors. Allergy principles and practice, Vol. 2. Saint Louis: Mosby; 1978. p. 659-73.

22. Rosalina I, Kartasasmita CB, Soepriadi M. Prevalence and risk factors of asthma in children aged 13-14 years. Pediatr Indones 1998;38:265-72.

23. Barnes PJ, Lundberg JM. Airways neuropeptides and asthma. In: Asthma: its pathology and treatment. Kaliner MA, Barnes PJ, Persson CGA, ED. New York: Marcel Dekker inc; 1991. p. 394.

24. Martinez FD, Antognoni G, Macri F, Bonci E, Midulla F, De Castro G, et al. Parental smoking enhances bronchial responsiveness nine-year-old children. Am Rev Respir Dis 1988;138:518-23.

25. Frischer T, Kuehr J, Meinert R, Karmaus W, Barth R, Hermann-Kunz E, et al. Maternal smoking in early child- hood: a risk factor for bronchial responsiveness to exercise in primary-school children. J Pediatr 1992;121:17-22.

26. Forastiere F, Agabiti N, Corbo GM, Pistelli R, Dell'Orco V, Ciappi G, et al. Passive smoking as a determinant of bronchial responsiveness in children. Am J Respir Crit Care Med 1994;149:365-70.

27. BackerV,Ulrik CS, Hansen KKLaursenEM, Dirksen A, BachMortensen N. Allergy and bronchial reactivity in children and adolescentsfrom Copenhagen. Ugeskr Laeger 1993;155:3982-6.

28. Postma DS, Bleecker ER, Amelung PJ, Holroyd KJ, Xu J, Panhuysen CIM, et al. Genetic susceptibility to asthmabronchial hyper-responsiveness coinherited with a major gene for atopy. N Engl J Med 1995;333:894-900.

29. Munasir Z. Uji provokasi bronkial. In: Akib AAP, Matondang CS. Buku ajar alergi-imunologi anak. Jakarta: BP IDAI; 1996. p. 317-9.

30. Annema JT, Sparrow D, O'Connor GT, Rijcken B, Koeter GH, Postma DS, et al. Chronic respiratory symptom and airway responsiveness to methacholine are associated with eosinophilia in older men: the normative aging study. Eur Respir J 1995;8:62-9.

31. Sont JK, Booms P, Bel EH, Vandenbroucke JP, Sterk PJ. The determinants of airway hyper-responsiveness to hypertonic saline in atopic asthma in vivo: Relationship with sub-populations of peripheral blood leucocytes. Clin Exp Allergy 1993;23:678-88.

32. Weller PF. Human eosinophils. J Allergy Clin Immunol 1997;100:283-7. 